Nurfadhilah, et al/Jurnal Ekonomi Syariah Teori dan Terapan Vol. 6 No. 2 Februari 2019: 344-352;

PEMBERDAYAAN LEMBAGA AMIL ZAKAT MASJID RUNGKUT JAYA SURABAYA DALAM MENINGKATKAN KESEJAHTERAAN MUSTAHIQ

\title{
PEMBERDAYAAN LEMBAGA AMIL ZAKAT MASJID RUNGKUT JAYA SURABAYA DALAM MENINGKATKAN KESEJAHTERAAN MUSTAHIQ
}

\author{
Rizky Farah Nurfadhilah \\ Departemen Ekonomi Syariah-Fakultas Ekonomi dan Bisnis-Universitas Airlangga \\ Email: rizkyfarahn@gmail.com \\ Ririn Tri Ratnasari \\ Departemen Ekonomi Syariah-Fakultas Ekonomi dan Bisnis-Universitas Airlangga \\ Email: ri.ratnasari@gmail.com
}

\begin{abstract}
:
The research method used in this paper is a qualitative method with a descriptiveanalytical case study method, which is an analysis that produces descriptive data in the form of written or oral words from people and behaviors that can be observed with a predetermined method. The purpose of this method is to minimize the results of research difficult to manipulate because researchers have little chance to control events that will occur. The event in question is the empowerment of the Amil Zakat Institution (LAZ) of Rungkut Jaya Mosque Surabaya in improving mustahiq welfare. Therefore, the data obtained from historical records are not enough, so interviews and direct observation are needed to be conducted. The research data was collected by interviewing the Chairperson of the LAZ Rungkut Jaya Mosque, the Chair of Ta'mir, two mustahiqs of LAZ Rungkut Jaya Mosque and two muzakkis of LAZ Rungkut Jaya Mosque.
\end{abstract}

Keywords: Empowerment of Amil Zakat Institutions, Amil Zakat Institutions, Zakat, Empowerment of Amil Zakat Institutions in Rungkut Jaya Mosque Surabaya, Mustahiq

\section{PENDAHULUAN}

\section{Latar Belakangan}

Salah satu permasalahan yang sering dihadapi oleh negara berkembang adalah masalah ekonomi, termasuk negara Indonesia saat ini. Permasalahan ekonomi sering kali berdampak negatif terhadap kehidupan sosial masyarakat, seperti kemiskinan dan pengangguran yang sering kali menimbulkan tindakantindakan criminal. Kemiskinan merupakan kondisi hidup yang serba kekurangan. Qardhawi (Miftah, 2008) menjelaskan kemiskinan merupakan salah satu penyebab munculnya permasalahan ekonomi karena lemahnya sumber penghasilan. Oleh karena itu, untuk mengatasi 1) Jurnal ini merupakan bagian dari skripsi Rizky Farah Nurfadhilah, NIM: 041311433096, yang diuji pada tanggal 17 Januari 2019.

problematika tersebut perlu adanya sebuah kebijakan untuk penanggulangan masalah kemiskinan. Menurut Mufraini (2006:161) sebagai negara yang penduduknya yang kurang lebih $90 \%$ beragama Islam, maka tuntunan dan kiat Islam dalam menginspirasi problematika kemiskinan umat menjadi penting untuk direalisasikan.

Permasalahan

kemiskinan bukanlah hal yang mudah untuk diselesaikan seperti halnya membalik tangan. Karena kemiskinan adalah bukti kekuasaan Allah SWT bahwa dengan kemiskinan Allah SWT ingin mengetahui sejauh mana kepedulian hamba-Nya yang diberi harta lebih untuk dapat berbagi dengan yang berkekurangan.
ah Nurfadhilah, NIM: 041311433096, yang 
Nurfadhilah, et al/Jurnal Ekonomi Syariah Teori dan Terapan Vol. 6 No. 2 Februari 2019: 344-352; PEMBERDAYAAN LEMBAGA AMIL ZAKAT MASJID RUNGKUT JAYA SURABAYA DALAM MENINGKATKAN KESEJAHTERAAN MUSTAHIQ

Islam menekankan adanya hubungan saling menolong di dalam lingkungan sosial umatnya.

$\begin{array}{ccc}\text { Dalam } & \text { ajaran } & \text { Islam } \\ \text { pemberantasan } & \text { kemiskinan } & \text { sudah }\end{array}$ dilembagakan dalam salah satu rukunnya, yaitu menunaikan zakat dan Islam juga menganjur berinfaq dan bersedekah (Al-Hamid, 2006:1). Pembayaran zakat sebagai sarana untuk mempersempit jurang perbedaan pendapatan dalam masyarakat, sehingga tidak terjadi kesenjangan sosial yang dapat berpotensi konflik dan mengganggu keharmonisan dalam bermasyarakat. Dengan demikian diharapkan dapat meningkatkan kesejahteraan hidup umat terutama dari golongan yang berhak menerima zakat. Dalam surat Al-Maidah ayat 55 dijelaskan perintah menunaikan zakat:

$$
\text { Artinya: "Sesungguhnya }
$$
penolong kamu hanyalah Allah, RasulNya, dan orang-orang yang beriman, yang mendirikan shalat dan menunaikan zakat, seraya mereka tunduk (kepada Allah)".

Zakat sendiri dibedakan lagi menjadi dua jenis, yakni zakat konsumtif dan zakat produktif. Zakat yang bersifat konsumtif adalah harta zakat secara langsung diperuntukkan bagi mereka yang tidak mampu dan sangat membutuhkan, terutama fakir miskin. Zakat konsumtif diberikan oleh mustahiq untuk menambah kemampuan konsumsinya yang sebelum zakat kurang untuk memenuhi kebutuhan dasarnya. Sedangkan zakat produktif adalah zakat yang diberikan kepada mustahiq yang bersifat lebih kepada tata cara pengelolaan zakat yang akan diberikan kepada mustahiq, dari yang sebelumnya hanya menjadi pemenuhan kebutuhan saja lalu diubah penyaluran dana zakat yang telah dihimpun tersebut kepada hal-hal yang bersifat produktif dalam rangka pemberdayaan umat. (Asnaini, 2007).

Oleh karena itu, zakat memiliki peranan yang sangat strategis dalam upaya pengentasan kemiskinan atau pembangunan ekonomi. Berbeda dengan sumber keuangan untuk pembangunan yang lain, zakat tidak memiliki dampak balik apapun kecuali ridha dan mengharap pahala dari Allah SWT semata. Zakat tidak hanya dimaknai sebagai sebuah ibadah semata yang diwajibkan kepada setiap umat Islam bagi yang sudah memenuhi syarat, akan tetapi dari pada itu, yakni sebagai sebuah sistem pendistribusian harta benda kalangan umat Islam dari si kaya kepada si miskin. Sehingga zakat mampu menghilangkan kesenjangan sosial ekonomi masyarakat (Qodir, 1998:214).

Sejahtera menurut Islam adalah tercapainya tujuan hidup manusia, yaitu mencapai al-falah, yaitu kebahagiaan di dunia dan di akhirat. Ukuran kebahagiaan tersebut adalah terpenuhinya kebutuhan dasar manusia, yaitu kebutuhan adh-dharutiyyaat yang terdiri dari lima hal: terlindunginya akal 
Nurfadhilah, et al/Jurnal Ekonomi Syariah Teori dan Terapan Vol. 6 No. 2 Februari 2019: 344-352; PEMBERDAYAAN LEMBAGA AMIL ZAKAT MASJID RUNGKUT JAYA SURABAYA DALAM MENINGKATKAN KESEJAHTERAAN MUSTAHIQ

(hifdzu al-aql), terlindunginya harta (hifdzu an-nafs), dan terlindunginya keturunan (hifdzu an-nasl). Kesemuanya itu disebut naqashid syariah atau tujuan syariah. (Azis dkk., 2017:46)

Untuk mencapai kebahagiaan (al-falah), seorang manusia harus terlindungi jiwanya (hifdzu an-nafs) dalam pengertian bahwa manusia harus terlindungi kemanusiaannya. Dalam Islam, jiwa tidak sekedar berarti fisik atau badan atau raga, namun jiwa mengandung pengertian jiwa yang tak tampak. Seorang manusia harus mampu untuk mencapai tingkatan jiwa muthmainnah, jiwa (nafs) yang tenang, sebagaimana diisyaratkan oleh Allah dalam Surah Al-Fajr ayat 27-30 (Zadjuli, 2010).

Di Indonesia, konsep pemberdayaan menguat seiring dengan penguatan demokratis dan pemulihan (recovery) krisis ekonomi. Hal ini disebabkan pascakrisis, jumlah penduduk yang tidak berdaya semakin besar. Pemberdayaan dapat diartikan sebagai tujuan dan proses. Sebagai tujuan, pemberdayaan adalah suatu keadaan yang ingin dicapai, yakni masyarakat yang memiliki kekuatan atau kekuasaan dan keberdayaan yang mengarah pada kemandirian. Fokus pemberdayaan adalah bagaimana setiap orang dapat memenuhi kebutuhan dasarnya secara mandiri dalam jangka panjang. Untuk itu, dalam pemberdayaan, mereka diberi suatu pengetahuan, keahlian, dan usaha yang dapat menjamin pemenuhyan kebutuhan dasarnya secara mandiri dalam jangka panjang. Bahkan, dalam konsep pemberdayaan melalui zakat, diharapkan para mustahiq dapat berdaya dan kemudian menjadi muzakki (Azis dkk., 2017:60).

Pemberdayaan menjadi fokus utama berbagai lembaga zakat di Indonesia. Pemberdayaan dinilai dapat memberikan daya dorong yang lebih kuat terhadap manfaat zakat, karena tidak saja untuk jangka pendek, tapi juga jangka panjang. Ryandono (2008) menjelaskan bahwa peran zakat dalam perekonomian tergantung dari bagaimana pengelolaannya. Apabila zakat hanya dipungut dan diberikan kepada yang berhak menerimanya (mustahia) secara langsung, maka zakat hanya akan memberikan daya dorong dalam jangka pendek dan bersifat sementara.

Berdasarkan latar belakang tersebut, penulis memandang perlu untuk meneliti dana zakat yang disalurkan, bagaimanakah pemberdayaan Lembaga Amil Zakat (untuk seterusnya dituliskan LAZ) Rungkut Jaya Surabaya dalam meningkatkan kesejahteraan mustahiq. Penulis menilai bahwa pemilihan objek penelitian LAZ Masjid Rungkut Jaya Surabaya cukup tepat sehingga akan membantu penulis untuk mendapatkan data yang cukup dalam penelitian ini.

\section{Rumusan Masalah}

Berdasarkan uraian latar 
Nurfadhilah, et al/Jurnal Ekonomi Syariah Teori dan Terapan Vol. 6 No. 2 Februari 2019: 344-352; PEMBERDAYAAN LEMBAGA AMIL ZAKAT MASJID RUNGKUT JAYA SURABAYA DALAM MENINGKATKAN KESEJAHTERAAN MUSTAHIQ

belakang di atas maka perumusan masalah dalam penelitian ini adalah Bagaimana pemberdayaan Lembaga Amil Zakat (LAZ) Masjid Rungkut Jaya Suraaya dalam meningkatkan kesejahteraan mustahiq?

\section{Tujuan Penelitian}

Berdasarkan latar belakang dan rumusan masalah yang dipaparkan dan dijelaskan di atas, maka tujuan dari penelitian ini adalah untuk mengetahui pemberdayaan Lembaga Amil Zakat (LAZ) Masjid Rungkut Jaya Surabaya dalam meningkatkan kesejahteraan mustahiq.

\section{LANDASAN TEORI}

Hafidhuddin (2002:5-6) mengemukakan bahwa pengumpulan, penyaluran dan potensi zakat sebagai instrument pengentasan kemiskinan selalu dikaitkan dengan ibadah yang mengandung dua dimensi. Dimensi hablum minallah atau dimensi vertikal dan dimensi hablum minannaas atau dimensi horizontal. Ibadah zakat yang dijalankan dengan baik akan meningkatkan kualitas keimanan. Zakat juga dapat membersihkan dan mensucikan jiwa, serta memberkahkan harta yang dimiliki. Jika dikelola dengan baik dan amanah, zakat dapat meningkatkan kesejahteraan umat sebagai instrument pemerataan ekonomi.

$\mathrm{Di}$ Indonesia, konsep
pemberdayaan menguat seiring
dengan penguatan demokratis dan

pemulihan (recovery) krisis ekonomi. Hal ini disebabkan pascakrisis, jumlah penduduk yang tidak berdaya semakin besar. Pemberdayaan dapat diartikan sebagai tujuan dan proses. Sebagai tujuan, pemberdayaan adalah suatu keadaan yang ingin dicapai, yakni masyarakat yang memiliki kekuatan atau kekuasaan dan keberdayaan yang mengarah pada kemandirian. Fokus pemberdayaan adalah bagaimana setiap orang dapat memenuhi kebutuhan dasarnya secara mandiri dalam jangka panjang. Untuk itu, dalam pemberdayaan, mereka diberi suatu pengetahuan, keahlian, dan usaha yang dapat menjamin pemenuhyan kebutuhan dasarnya secara mandiri dalam jangka panjang. Bahkan, dalam konsep pemberdayaan melalui zakat, diharapkan para mustahiq dapat berdaya dan kemudian menjadi muzakki. (Azis dkk., 2017:60)

Oleh karena itu, dari delapan ashnaf yang berhak menerima zakat, pemberdayaan pada umumnya difokuskan kepada dua ashnaf saja, yaitu fakir dan miskin. Fakir adalah seseorang yang tidak memiliki pekerjaan dan tidak memiliki pendapatan tetap untuk menghidupi diri sendiri maupun keluarga. Sementara itu, miskin adalah kondisi seseorang yang memiliki pekerjaan (pendapatan), tetapi pendapatannya tidak cukup untuk memenuhi kebutuhan hidup diri sendiri dan keluarganya. Dengan demikian, kondisi miskin ini lebih baik 
Nurfadhilah, et al/Jurnal Ekonomi Syariah Teori dan Terapan Vol. 6 No. 2 Februari 2019: 344-352; PEMBERDAYAAN LEMBAGA AMIL ZAKAT MASJID RUNGKUT JAYA SURABAYA DALAM MENINGKATKAN KESEJAHTERAAN MUSTAHIQ

daripada fakir, sehingga dalam penyaluran zakat, fakir menjadi prioritas.

Pemberdayaan menjadi fokus utama berbagai lembaga zakat di Indonesia. Pemberdayaan dinilai dapat memberikan daya dorong yang lebih kuat terhadap manfaat zakat, karena tidak saja untuk jangka pendek, tapi juga jangka panjang. Ryandono (2008) menjelaskan bahwa peran zakat dalam perekonomian tergantung dari bagaimana pengelolaannya. Apabila zakat hanya dipungut dan diberikan kepada yang berhak menerimanya (mustahiq) secara langsung, maka zakat hanya akan memberikan daya dorong dalam jangka pendek dan bersifat sementara.

\section{METODE PENELITIAN}

Alasan penggunaan strategi studi kasus deskriptif adalah; pertama, studi kasus deskriptif memungkinkan hasil penelitian sulit dimanipulasi karena peneliti hanya memiliki sedikit peluang untuk mengontrol peristiwa-peristiwa yang akan terjadi. Peristiwa yang dimaksud adalah pemberdayaan LAZ Masjid Rungkut Jaya Surabaya dalam meningkatkan kesejahteraan mustahiq. Kedua, fokus penelitian terletak pada fenomena dalam kehidupan nyata masyarakat dan para pengelola LAZ Masjid Rungkut Jaya Surabaya, sehingga data yang dibutuhkan tidak cukup data historis melainkan diperlukan wawancara, dan observasi langsung di lapangan.
Komponen ini berkaitan dengan masalah penelitian apa yang dimaksud dengan "kasus" dalam penelitian yang telah menjadi pembahasan diawal studi kasusnya. Unit analisis merupakan individu, kelompok, serta pihak lain yang memberikan respon terhadap tindakan yang dilakukan peneliti dalam penelitiannya (Moleong, 1988:14). Unit analisis yang digunakan dalam penelitian ini adalah pemberdayaan zakat produktif LAZ Masjid Rungkut Jaya Surabaya dalam meningkatkan kesejahteraan mustahiq.Dalam penelitian ini diperlukan dua jenis data yakni data primer dan data sekunder, masing-masing memiliki cara pengumpulan yang berbeda. Berikut tahapan-tahapan yang dilakukan dalam penelitian ini :

1. Data Primer

a. Persiapan Awal

Sebelum dimulainya penelitian, peneliti perlu mengurus surat izin penelitian skripsi secara formal pada bagian akademik Fakultas Ekonomi dan Bisnis (FEB) Universitas Airlangga sebagai pelengkap untuk melakukan penelitian di LAZ Masjid Rungkut Jaya Surabaya.

Pada tahap ini peneliti akan melakukan pengamatan awal di LAZ Masjid Rungkut Jaya Surabaya untuk mendapatkan informasi-informasi yang sesuai dengan maksud dan tujuan penelitian, sehingga mampu menjawab rumusan masalah yang dicari peneliti.

b. Proses saat di lokasi atau objek penelitian 
Nurfadhilah, et al/Jurnal Ekonomi Syariah Teori dan Terapan Vol. 6 No. 2 Februari 2019: 344-352; PEMBERDAYAAN LEMBAGA AMIL ZAKAT MASJID RUNGKUT JAYA SURABAYA DALAM MENINGKATKAN KESEJAHTERAAN MUSTAHIQ

Pada tahap ini, peneliti mendatangi kantor LAZ Masjid Rungkut Jaya Surabaya dengan membawa surat izin penelitian skripsi secara formal dari Fakultas Ekonomi dan Bisnis Universitas Airlangga. Setelah mendapatkan izin untuk melakukan penelitian di LAZ Masjid Rungkut Jaya tersebut, peneliti melakukan observasi secara langsung di LAZ Masjid Rungkut Jaya Surabaya secara terus menerus dan berlanjut hingga peneliti mendapatkan jawaban dari rumusan masalah yang telah dibuat sebelumnya.

c. Saat Pengumpulan Data

Pada tahapan ini, peneliti melakukan observasi dan wawancara secara mendalam terhadap pihak pengurus LAZ Masjid Rungkut Jaya Surabaya dan mustahiq yang memperoleh dana zakat sebagai informan. Wawancara kepada informan akan dilakukan dengan mengajukan pertanyaan-pertanyaan yang berfokus dan mengarah pada topik penelitian. Tahap selanjutnya adalah mengumpulkan hasil observasi dan wawancara dari objek penelitian yang akan didokumentasikan sendiri oleh peneliti.

2. Data Sekunder

Pengumpulan data sekunder yang diperoleh berasal dari laporan mekanisme pelaksanaan pengumpulan dana zakat yang dimiliki oleh LAZ Masjid Rungkut Jaya Surabaya. Dilakukan juga melalui kajian pustaka dan literatur yang berkaitan tentang pemberdayaan
Lembaga Amil Zakat dalam meningkatkan kesejahteraan mustahiq. Data diperoleh dari buku, referensi skripsi tahun sebelumnya, jurnal dan artikel yang berkaitan, serta media internet.

\section{HASIL DAN PEMBAHASAN}

Sub bab ini akan menjelaskan hasil temuan penelitian secara deskriptif dari yang merupakan temuan-temuan selama melakukan proses penelitian.

1. Sumber perolehan dana Lembaga Amil Zakat Masjid Rungkut Jaya Surabaya.

Dana yang digunakan berasal dari dana zakat dan infak. Dana tersebut dihimpun oleh Lembaga Amil Zakat Masjid Rungkut Jaya Surabaya dari para donatur untuk kemudian disalurkan kepada mereka yang membutuhkan, khususnya mereka yang nyaris putus sekolah karena tidak mampu membayar SPP.

2. Bentuk pemberdayaan Lembaga Amil Zakat Masjid Rungkut Jaya Surabaya.

Bentuk pemberdayaan Lembaga Amil Zakat Masjid Rungkut Jaya Surabaya yang fokus utamanya adalah bidang pendidikan yaitu dengan memberikan bantuan dana bagi mereka yang tidak mampu membayar zakat, serta memberikan modal pada para pedagang yang membutuhkan modal. Kriteria siswa yang 
Nurfadhilah, et al/Jurnal Ekonomi Syariah Teori dan Terapan Vol. 6 No. 2 Februari 2019: 344-352; PEMBERDAYAAN LEMBAGA AMIL ZAKAT MASJID RUNGKUT JAYA SURABAYA DALAM MENINGKATKAN KESEJAHTERAAN MUSTAHIQ

berhak mendapatkan bantuan dari Lembaga Amil Zakat Masjid Rungkut Jaya Surabaya adalah para generasi yang hampir putus sekolah yang tidak mampu membayar SPP. Dana bantuan yang diberikan terus disalurkan hingga siswa tersebut lulus sekolah.

3. Perubahan sebelum dan sesudah menjadi mustahia Lembaga Amil Zakat Masjid Rungkut Jaya Surabaya.

Terdapat perbedaan yang mereka rasa saat sebelum dan sesudah menjadi mustahia di Lembaga Amil Zakat Masjid Rungkut Jaya Surabaya. Bagi mustahiq perubahan tersebut meliputi kebutuhan siswa yang menjadi terpenuhi saat daftar ulang, dapat memiliki buku pelajaran yang lengkap, mampu membayar SPP, dapat mengambil rapor, dan siswa menjadi tidak minder, begitu juga terhadap orang tua siswa dapat meringankan beban mereka.

\section{PENUTUP}

\section{SIMPULAN}

Berdasarkan analisis dan pembahasan, maka diperoleh simpulan bahwa Lembaga Amil Zakat Masjid Rungkut Jaya Surabaya sudah meningkatkan kesejahteraan mustahiq. Hal tersebut berdasarkan pernyataan dari informan bahwa dengan adanya bantuan dana zakat baik berupa modal untuk berdagang maupun bantuan untuk membayar SPP anak-anak sekolah yang tidak mampu, Lembaga Amil Zakat Masjid Rungkut Jaya Surabaya merubah kehidupan mereka menjadi lebih baik.

Terdapat temuan lain di luar pertanyaan protokol yang berkaitan dengan pemberdayaan Lembaga Amil Zakat Masjid Rungkut Jaya untuk meningkatkan kesejahteraan mustahiq, yaitu upaya lembaga zakat tersebut untuk mengupayakan saldo harus habis terbagi dengan cara jika ada dana yang dihimpun terlalu banyak, dana tersebut tidak hanya diberikan pada masyarakat sekitar yang mengalami musibah atau kesulitan dalam hal ekonominya, tetapi juga disalurkan pada pedagang sekitar seperti penjual ikan yang membutuhkan modal. Lalu fokus utamanya terkini yaitu meningkatkan kesejahteraan mustahiq melalui bidang pendidikan dengan cara menyalurkan dana zakat kepada siswa yang tidak mampu membayar SPP hingga siswa tersebut lulus sekolah.

Saran

Saran yang dapat diberikan berdasarkan hasil analisis dalam penelitian ini adalah :

A. Bagi Lembaga Amil Zakat Masjid Rungkut Jaya Surabaya

Bagi LAZ Masjid Rungkut Jaya Surabaya hendaknya memperbesar anggota kepengurusan dengan mengajak jamaah masjid untuk 
Nurfadhilah, et al/Jurnal Ekonomi Syariah Teori dan Terapan Vol. 6 No. 2 Februari 2019: 344-352; PEMBERDAYAAN LEMBAGA AMIL ZAKAT MASJID RUNGKUT JAYA SURABAYA DALAM MENINGKATKAN KESEJAHTERAAN MUSTAHIQ

bergabung, terutama remaja masjid. Adapun dengan cara lain yaitu mencari data pengangguran di kecamatan atau kelurahan sekitar Masjid Rungkut Jaya untuk merekomendasikan menjadi anggota kepengurusan LAZ Masjid Rungkut Jaya, sehingga lembaga zakat ini dapat berkembang.

B. Bagi Peneliti Selanjutnya Penelitian ini masih banyak terdapat kekurangan dan keterbatasan, sehingga perlu dilakukan penelitian yang lebih mendalam bagi peneliti selanjutnya tentang pemberdayaan LAZ Masjid Rungkut Jaya Surabaya dalam meningkatkan kesejahteraan mustahiq.

\section{DAFTAR PUSTAKA}

Al-Ba'ly, Abdul Al Hamid Mahmud. 2006. Ekonomi Zakat: Sebuah Kajian Moneter dan Keuangan Syariah. Jakarta: PT. Raja Grafindo Persada. hlm. 1.

Al-Ghazali, Ihya Ulumuddin, Juz II, Mesir: Multazam At-Taba' Wannasar, t, t.

Ali, M. Daud. 1998. Sistem Ekonomi Islam Zakat dan Waqaf. Jakarta: UIPress. hlm. 39.

Arifin, Zainul. Memahami Bank Syari'ah Lingkup, Peluang, Tantangan dan Prospek. Jakarta: Alvabet, 2000.

Ash-Shiddieqy, Muhammad Hasbi. 2009. Pedoman Zakat. Semarang: PT. Pustaka Rizki Putra. hlm. 162.
Asnaini. 2007. Zakat Produktif Dalam Perspektif Hukum Islam. Yogyakarta: Pustaka Pelajar. 2008. Zakat Produktif Dalam Perspektif Hukum Islam. Yogyakarta: Pustaka Pelajar. hIm. 12.

Aziz, H.A, dkk. 2017. Zakat Dan Pemberdayaan. Surabaya: Airlangga University Press.

Djuanda, Gustian et, al. 2006. Pelaporan Zakat Pengurang Pajak Penghasilan. Jakarta: Raja Grafindo Persada. hlm. 15-17.

Hafidhuddin, Didin. 2002. Zakat Dalam Perekonomian Modern. Jakarta: Gema Insani Press.

Huda, Nurul. Muhammad Heykal. 2010. Lembaga Keuangan Islam: Tinjauan Teoritis dan Praktis. Jakarta: Prenada Media Group.

Mannan, Abdul. 1997. Teori dan Praktik Ekonomi Islam. Yogyakarta: PT. Dana Bhakti Prima Yasa. hlm. 285.

Miftah. 2008. Pembaharuan Zakat Untuk Pengentasan Kemiskinan di Indonesia. Innovatio, Vol. VII, No. 14, Juli-Desember 2008. hlm. 425. Moleong. 1998. Metodologi Penelitian Kualitatif. Bandung: CV. Remaja Rosdakarya.

2007. Metodologi Penelitian Kualitatif. Bandung: CV. Remaja Rosdakarya.

Mufraini, Arief. 2006. Akutansi dan Manajemen Zakat, Mengomunikasikan Kesadaran 
Nurfadhilah, et al/Jurnal Ekonomi Syariah Teori dan Terapan Vol. 6 No. 2 Februari 2019: 344-352;

PEMBERDAYAAN LEMBAGA AMIL ZAKAT MASJID RUNGKUT JAYA SURABAYA DALAM MENINGKATKAN KESEJAHTERAAN MUSTAHIQ

\author{
dan Membangun Jaringan. \\ Jakarta : Kencana Prenada \\ Media Grup. hlm. 161.
}

Muhammad, \& Bakar, Abu. 2011.

Manajemen Organisasi Zakat.

Malang: Madani Wisma

Kalimetro.

Mu'inan, Rafi'. 2011. Potensi Zakat (dari konsumtif-karikatif ke produktif berdayaguna perspektif hukum Islam). Yogyakarta: Citra Pustaka. hlm. 132.

Qardhawi, Yusuf, DR. 1999. Fiqih AzZakat, Bandung: Mizan. 